\title{
Making Sense of Sustainable Project Management
}

\author{
Gilbert Silvius* \\ LOI University of Applied Sciences, University of Johannesburg, South Africa
}

Submission: December 06, 2018; Published: January 18, 2019

*Corresponding author: Gilbert Silvius, LOI University of Applied Sciences, the Netherlands, and University of Johannesburg, South Africa

\section{Introduction}

Sustainability is one of the most important challenges of our time. How can we develop prosperity, without compromising the life of future generations? The pressure on companies to consider sustainability in their business practices is increasing, and the integration of sustainability into core business functions is considered one of the most important leadership challenge facing business today [1]. Integration of the principles of sustainability requires rethinking and redevelopment of business strategies, products/services, processes and resources [2].

In the implementation of strategies, projects play an essential role, and this also applies to sustainability strategies [3]. Marcelino-Sádaba et al. [4] therefore conclude that "Organizations, nowadays are increasingly keen on to include sustainability in their business. Project management can help make this process a success". The relationship between sustainability and project management is being addressed in a growing number of studies and publications [5,6] and 'green' or 'sustainable' project management is considered one of the most important global project management trends today $[7,8]$. This short article aims to provide guidance on the understanding of this emerging theme of sustainable project management, by discussing the main aspects and topics discussed in literature. In the conclusion of the article, the author will develop an overview model that links the different topics and aspects to each other.

\section{Sustainability in Project Management}

As project management is often described in a life-cycle of project management processes or process groups, for example initiating - planning - implementing - controlling - closing [9], it is not surprising that several authors apply this perspective in their analysis of the impact of sustainability on project management. An early study that took this perspective was done by Eid [10]. In this study, a forum of project management practitioners was asked about the impact of sustainable development on project management processes. The respondents saw opportunities for the integration of sustainability in all process groups, however, the area of integration of sustainability aspects, differed. In their view, the initiating and planning processes of the project provided opportunities for integrating sustainability into the content of the project, whereas the executing and controlling processes of the project provided opportunity for integrating sustainability into the processes of the project.

This differentiation between the impact of sustainability on the content of the project, and thereby the deliverable or product of the project, and the processes in the project, that realize the deliverable or manage this realization, can also be found in other publications $[11,12]$. However, in one of the first publications on sustainability and project management, Labuschagne and Brent [13] link process and product by elaborating the concept of lifecycle orientation to the project life-cycle. In the context of projects, the concept of life-cycle orientation, logically implies that the full life-cycle of a project, from its conception to its disposal, should be considered. Labuschagne and Brent argue that when considering sustainability in project management, not just the total life-cycle of the project should be considered, but also of the 'result' the project produces, being a change in products, assets, systems, processes or behavior. In other words, considering sustainability in project management suggests that both the process and the product of the project need to be considered [2].

Next to the processes of the project life-cycle, project management is often also described in content related themes, addressed as knowledge areas [14], subject groups [9] or themes [15]. Also, these themes provide a structure for analysis of the impact of sustainability on project management. For example, based on a structured analysis of 164 publications on sustainability in project management, Silvius and Schipper [5] conclude several 'areas of impact' of sustainability that largely coincide with the content related themes of project management. Other studies focus on specific themes, such as specifications [10, 6] , stakeholder management $[16,17,18]$, procurement [19], risk management [20], communication [21], materials [22], business case [23,24], quality [25], success [26] and the project team [5].

Studies that focus on the content related aspects of projects often focus on operationalizing the 'Triple Bottom Line' concept of sustainability [27] by developing sets of indicators on the different perspectives of the Triple Bottom Line concept [28], for example [28-31]. However, addressing sustainability through a 
set of indicators tends to be more adequate for the content and product of the project than for the delivery and management processes of it [32]. For this, a more process related view, based on a set of guiding principles, such as the UN Global Compact, should be preferred $[33,34]$. In short, principles provide guidance for future behavior, where indicators measure the impact of past behavior. Both are relevant, but principles are more useful in the assessment of project management processes, whereas indicators are more useful in the assessment of project deliverables and products.

So far, this article has addressed that the impact of sustainability on project management is analyzed in academic studies by applying either principles or indicators of sustainability to project management processes and/or themes. However, sustainable project management in the end evolves about the behavior of the project manager. And despite the growing attention for sustainability in project management, Økland [35] still observes a gap between the literature on sustainability in project management and what is carried out in practice.

The behavior of the project manager with regards to sustainability has been addressed in the study by Silvius, Schipper \& Visser [36]. They found that the beliefs of the project manager with regards to sustainability play a key role in his/her behavior. Some project managers are intrinsically motivated to consider sustainability. They care about nature, the planet and the future and they feel that considering sustainability is something they should do. The characteristics of the project, or the opinion of others, probably do not play a large role in this behavior. These project managers will consider sustainability because they consider it 'the right thing to do'.

Another group of project manager is less self-motivated and more task-oriented. They will consider sustainability when it is part of the project's requirements or objectives, when the client asks for it or when they are rewarded for it. This group is sensitive to the opinion of the project owner on sustainability and can be stimulated to consider sustainability by external pressure or rewards. The third group of project managers is most of all pragmatic. This group is also not strongly self-motivated for sustainability but will consider it when they see a good application. This group is stimulated by practical knowledge, tools and instruments [36]. Sustainability may be understood intuitively, but remains difficult to express in concrete, operational terms [37]. Unfortunately, the literature still provides "little guidance ... on how to apply sustainability to specific projects" [4] and these practical tools are less developed.

A specifically sustainability-oriented standard for project management is Projects Integrating Sustainability Methods Prism [38]. Prism is based upon the ISO 21500 project management processes [9] and integrates the consideration of sustainability into these processes. It does so by integrating a sustainability impact analysis in the project initiating phase, that feeds into a Project "Sustainability Management Plan" (PSMP) for the project. The PSMP is managed throughout the life-cycle of the project, and during the initiation and the closure of the project. The sustainability aspects aspects are reviewed in a meeting that includes also the sustainability or CSR officer of the organization. Silvius [39] developed a template for this PSMP and reported the first experiences with the application of it [40]. The findings of this study show that the development of a PSMP for a project provides an added value to both the projects and the organizations involved.

An important part of an PSMP is the analysis of the sustainability impact of the project at hand. In the last years, several structured 'project sustainability impact analysis' instruments have been published (For example the Sustainable Footprint Methodology [41], the Sustainability Project Management Maturity Model (SPM3) [11], the P5 standard for sustainability in project management [42], the Project Sustainability Excellence Model (PSEM) [43] and the Project Sustainability Impact Assessment (PSIA) [44]. It is hard to say which instrument is most used, but the experiences with the SPM3 model are documented in several publications $[45,46]$.

Next to tools and instruments, project managers also need competences to be able to assess the sustainability of their projects. The IPMA Individual Competence Baseline version 4 [47], explicitly addresses this competence, by stating that the project manager should be able to "assess the impact of the project on the environment and society" and that he/she "researches, recommends and applies measures to limit or compensate negative consequences". Silvius and Schipper [48] analyze what competences the project manager would need to be able to assess this impact and conclude that project managers may typically be strong on the 'strategic' and 'interpersonal' competences that are required to assess sustainability. However, they also conclude that the 'anticipatory', 'systems thinking' and 'normative' competences are less present in project management competency standards.

\section{Conclusion}

This article intended to give some insights into the different views and aspects that can be found in the emerging literature on sustainable project management. Based on the observations described above, we constructed the following overview model (Figure 1). At the heart of the model are the actions and the behavior of the project manager. Sustainable project management needs to be substantiated in actions and behavior that consider sustainability, otherwise nothing will happen. What sustainability means for a specific project, can be derived from the numerous publications that show principles or criteria/indicators of sustainability. Principles are more useful in the assessment of project management processes, whereas indicators are more useful in the assessment of project deliverables and products. It is important to realize that the materiality of sustainability indicators will depend on the type of project and the industry in which the project takes place. The criteria that are applied to assess the sustainability impact of a project should therefore be aligned with the strategy and values of the organizations involved. 


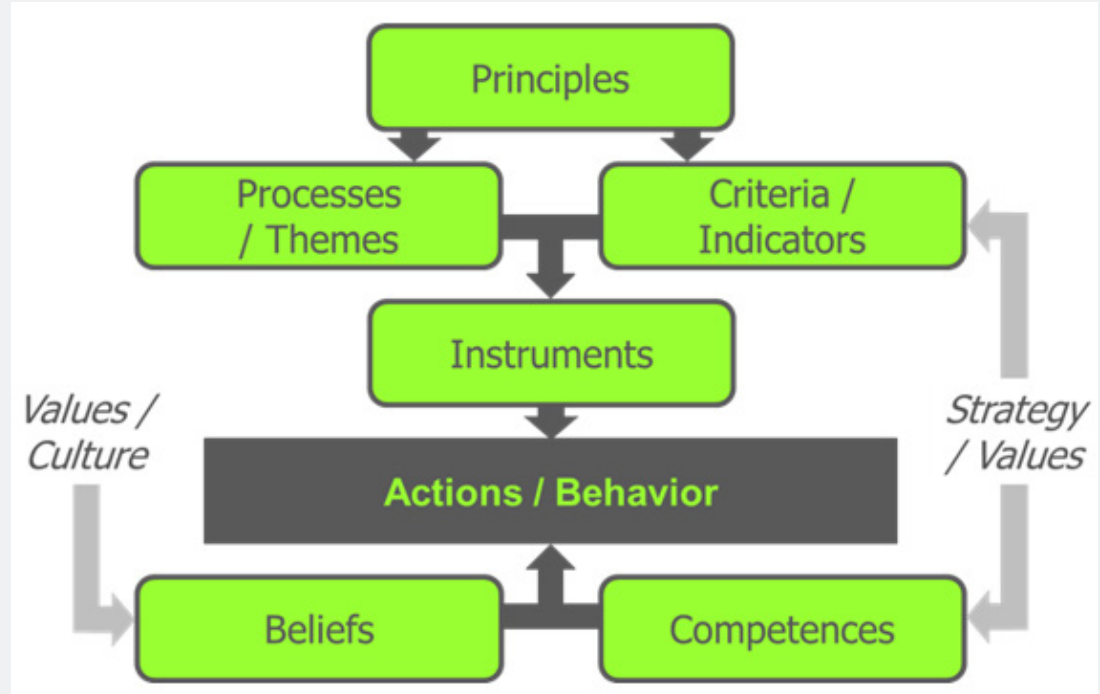

Figure 1: An overview of Sustainable Project Management.

How sustainability may or should impact project management processes and themes has also been addressed in several publications. However, in order to influence the behavior of the project manager, these impacts need to be operationalized in practical tools and instruments. Project managers in general do not have the time to 'translate' models and conceptual views into practical instruments. We rely on authors, standards and researchers to 'package' the sustainability perspective in practically applicable tools, in order to change the behavior of project managers.

Next to instruments and tools, the project managers also need to be educated in what sustainability is and how they can integrate it into their projects. Building sustainability competences lets individuals see and understand more about sustainability, which creates awareness and may also change individual beliefs. Also, in these believes, the values and culture of the organization plays a role.

With the overview model presented in this short article, the author aims to provide the readers with a 'map' that will help them to position publications and studies on the topic and to 'make sense' of Sustainable Project Management.

\section{References}

1. BSR/GlobeScan (2012) 2012 BSR/GlobeScan State of Sustainable Business Poll, London, UK.

2. Silvius AJG, Schipper, Planko, Van Den Brink, Köhler (2012) Sustainability in Project Management, Gower Publishing, Farnham.

3. Schipper, R, Silvius, AJG (2018) Towards a conceptual framework for sustainable project portfolio management. International Journal of Project Organisation and Management 10(3): 191-221.

4. Marcelino-Sádaba, Pérez-Ezcurdia, A, González-Jaen, LF (2015) Using Project Management to sustainability. From a comprehensive review to a framework definition. Journal of Cleaner Production 99: 1-16.

5. Silvius, AJG, Schipper, R (2014) Sustainability in Project Management: A literature review and impact analysis. Social Business 4(1).
6. Aarseth, Ahola, Aaltonen, Økland, Andersen (2017) Project sustainability strategies: A systematic literature review. International Journal of Project Management 35(6): 1071-1083.

7. Alvarez-Dionisi, LE, Turner, Mittra, M (2016) Global Project Management Trends. International Journal of Information Technology Project Management 7(3): 54-73.

8. Gemünden, HG (2016) Project Governance and Sustainability-Two Major Themes in Project Management Research and Practice. Project Management Journal 47(6): 3-6.

9. International Organisation for Standardisation (2012) ISO 21500:2012, Guidance on Project Management, Geneva.

10. Eid, M (2009) Sustainable Development \& Project Management, Lambert Academic Publishing, Cologne 2: 2.

11. Silvius, AJG, Schipper, R (2015) Developing a Maturity Model for Assessing Sustainable Project Management. Journal of Modern Project Management 3(1): 16-27.

12. Kivilä, J, Martinsuo, M, Vuorinen (2017) Sustainable project management through project control in infrastructure projects. International Journal of Project Management 35(6): 1167-1183.

13. Labuschagne, C, Brent, AC (2005) Sustainable Project Life Cycle Management: the need to integrate life cycles in the manufacturing sector. International Journal of Project Management 23(2): 159-168.

14. Project Management Institute (2017) A Guide to Project Management Body of Knowledge' (PMBOK Guide), Sixth edition, Project Management Institute, Newtown Square.

15. Office of Government Commerce (2009) Managing Successful Projects with PRINCE2, Norwich.

16. Eskerod, P, Huemann, M (2013) Sustainable development and project stakeholder management: what standards say. International Journal of Managing Projects in Business 6(1): 36-50.

17. Labelle, F, Leyrie, C (2013) Stakepartner Management in Projects. The Journal of Modern Project Management 1: 1.

18. Bal, Bryde, Fearon, Ochieng (2013) Stakeholder Engagement: Achieving Sustainability in the Construction Sector. Sustainability 6: 695-710.

19. Molenaar, KR, Sobin, N (2010) A synthesis of best-value procurement practices for sustainable design-build projects in the public sector. Journal of Green Building 5(4): 148-157. 


\section{Annals of Social Sciences \& Management studies}

20. Silvius, AJG (2016) Integrating sustainability into project risk management. In Bodea, S Purnus, A, Huemann, M Hajdu, M (Eds.), Managing Project Risks for Competitive Advantage in Changing Business Environments, IGI Global.

21. Pade, C, Mallinson, B, Sewry (2008) An Elaboration of Critical Success Factors for Rural ICT Project Sustainability in Developing Countries: Exploring the Dwesa Case. The Journal of Information Technology Case and Application 10: 4.

22. Akadiri, PO (2015) Understanding barriers affecting the selection of sustainable materials in building projects. Journal of Building Engineering 4: 86-93.

23. Silvius, AJG (2015) Sustainability Evaluation of IT/IS Projects. International Journal of Green Computing 6(2): 1-15.

24. Weninger, C, Huemann, M (2013) Project Initiation: Investment Analysis for Sustainable Development. In Silvius AJG, Tharp, J (Eds.) Sustainability Integration for Effective Project Management, IGI Global Publishing.

25. Maltzman, R, Shirley, D (2011) Green Project Management. CRC press, Boca Raton, FL USA.

26. Martens, M, Carvalho, MM (2016) Sustainability and Success Variables in the Project Management Context: An Expert Panel. Project Management Journal 47(6): 24-43.

27. Elkington, J (1997) Cannibals with Forks: The Triple Bottom Line of 21st Century Business, Capstone Publishing Ltc., Oxford.

28. Bell, Morse, S (2003) Measuring Sustainability Learning from doing, Earthscan, London.

29. Keeble, JJ, Topiol, Berkeley, S (2003) Using Indicators to Measure Sustainability Performance at a Corporate and Project Level. Journal of Business Ethics 44(2-3): 149-158.

30. Labuschagne, C, Brent, AC (2006) Social indicators for sustainable project and technology life cycle management in the process industry. International Journal of Life Cycle Assessment 11(1): 3-15.

31. Martens, ML, Carvalho, MM (2017) Key factors of sustainability in project management context: A survey exploring the project managers perspective. International Journal of Project Management 35(6): 10841102.

32. Gareis, Huemann, Martinuzzi, Weninger, Sedlacko (2013) Project Management \& Sustainable Development Principles, Project Management Institute, Newtown Square, PA USA.

33. Hopwood W, Mellor, O'Brien, G (2005) Sustainable development: mapping different approaches. Sustainable Development 13: 38-52.
34. Fergus, AHT, Rowney, JIA (2005) Sustainable Development: Lost Meaning and Opportunity? Journal of Business Ethics, 60: 17-27.

35. Økland, A (2015) Gap analysis for incorporating sustainability in project management. Procedia Computer Science 64: 103-109.

36. Silvius, AJG, Schipper, Visser, M (2017) Exploring factors that stimulate project managers to consider sustainability. IRNOP conference, Boston.

37. Briassoulis, H (2001) Sustainable Development and its Indicators: Through a (Planner's) Glass Darkly. Journal of Environmental Planning and Management 44(3): 409-427.

38. Carboni, Duncan, González, Milson, Young (2018) Sustainable Project Management: The GPM Reference Guide, GPM Global, USA.

39. Silvius, A.J.G. (2015), Model Project SMP.

40. Silvius, AJG, Neuvonen, Eerola, S (2017) Evaluating projects from a sustainability perspective: Experiences with developing a Project Sustainability Management Plan, 24th Nordic Academy of Management Conference, Bodø.

41. Oehlmann, I (2011) The Sustainable Footprint Methodology, Lambert Academic Publishing, Cologne 2: 2.

42. GPM Global (2016) P5 Standard for Sustainability in Project Management Version 1.5.1, GPM Global, USA.

43. Szabo, L (2016) Sustainability, Creativity and Innovation in Project Management. Vezetéstudomány/Budapest Management Review 47(10): 3-18.

44. Tam, G (2017) Managerial Strategies and Green Solutions for Project Sustainability, IGI Global Publishing, China.

45. Simionescu, V, Silvius, AJG (2016) Assessing Sustainability of Railway Modernization Projects; A Case Study from Romania. Procedia Computer Science 100: 458-465.

46. Clinning, G, Marnewick, C (2017) Incorporating sustainability into IT project management in South Africa. South African Computer Journal 29(1): $1-26$

47. International Project Management Association (2015) Individual Competence Baseline for Project, Programme \& Portfolio Management, $4^{\text {th }}$ version, Nijkerk.

48. Silvius, AJG, Schipper, R (2014) Sustainability in Project Management Competencies: Analyzing the Competence Gap of Project Managers. Journal of Human Resource and Sustainability Studies 2(2): 40-58.

\begin{tabular}{l} 
Your next submission with Juniper Publishers \\
will reach you the below assets \\
- Quality Editorial service \\
- Swift Peer Review \\
- Reprints availability \\
- E-prints Service \\
- Manuscript Podcast for convenient understanding \\
- Global attainment for your research \\
- Manuscript accessibility in different formats \\
( Pdf, E-pub, Full Text, Audio) \\
- Unceasing customer service \\
Track the below URL for one-step submission \\
https://juniperpublishers.com/online-submission.php \\
\hline
\end{tabular}

